\title{
Fluctuating Asymmetry Increases with Heat Stress Disruptions on Bali Cattle (Bos javanicus) at Different Altitude
}

\author{
Suhendro $\mathrm{I}^{1,2}$, Jakaria $\mathrm{J}^{2}$, Priyanto $\mathrm{R}^{2}$, Manalu $\mathrm{W}^{3}$, Noor $\mathrm{RR}^{2} *$ \\ ${ }^{I}$ Postgraduate student of Animal Production and Technology, IPB University \\ ${ }^{2}$ Department of Animal Production and Technology, Faculty of Animal Science, IPB University, Bogor, Indonesia \\ 3Faculty of Veterinary Medicine, IPB University, Bogor, Indonesia \\ *Corresponding Author: ronny_noor@yahoo.com
}

(received 10-06-2021; revised 04-08-2021; accepted 09-08-2021)

\begin{abstract}
ABSTRAK
Suhendro I, Jakaria J, Priyanto R, Manalu W, Noor RR. 2021. Fluktuasi asimetris meningkat seiring dengan gangguan stres panas pada Sapi Bali (Bos javanicus) di ketinggian yang berbeda. JITV 26(3):89-95 DOI: http://dx.doi.org/10.14334/jitv.v26i3.2758.

Sapi Bali (Bos javanicus) merupakan spesies yang umum tersebar di seluruh Indonesia dan dapat bertahan hidup di iklim tropis yang panas dan lembap. Fluktuasi asimetris (FA) adalah penyimpangan acak dari simetri bilateral sempurna. FA sering digunakan untuk mengukur stabilitas perkembangan pada individu dan dapat digunakan sebagai penanda dampak stres lingkungan dan genetik. Penelitian ini bertujuan untuk mengetahui pola ketidakstabilan perkembangan sapi Bali akibat cekaman lingkungan pada berbagai ketinggian tempat dengan menggunakan indeks FA. Indeks FA dalam penelitian ini digunakan untuk membandingkan asimetris ciri fisik sapi Bali di dataran tinggi Sembalun dan dataran rendah Serading. Enam puluh lima ekor sapi Bali yang digunakan dalam penelitian ini dipelihara pada ketinggian yang berbeda, yaitu Serading, Pulau Sumbawa (50 m dpl), dan Sembalun, Pulau Lombok (1.186 m dpl). Sifat fisik sapi Bali yang diukur adalah lingkar tanduk (tanduk), jarak pinggul ke tulang belakang (panggul), lingkar metatarsal (metatarsal), dan lingkar metakarpal (metakarpal). Indeks FA1 dan FA5 menunjukkan perbedaan metakarpal yang signifikan antara sapi Bali yang dipelihara di populasi Sembalun dan Serading $(\mathrm{P}<0,05)$. Indeks sifat ganda FA11 sebagai kombinasi dari semua sifat juga menunjukkan perbedaan yang nyata $(\mathrm{P}<0,01)$. Dapat disimpulkan bahwa variasi cekaman panas menurut ketinggian mempengaruhi asimetris sapi bali.
\end{abstract}

Kata Kunci: Altitud, Fluktuasi asimetris, Sapi Bali, Stres panas

\section{ABSTRACT}

Suhendro I, Jakaria J, Priyanto R, Manalu W, Noor RR. 2021. Fluctuating asymmetry increases with heat stress disruptions on Bali cattle (Bos javanicus) at different altitude. JITV 26(3): 89-95 DOI: http://dx.doi.org/10.14334/jitv.v26i3.2758.

Bali cattle (Bos javanicus) are common species distributed throughout Indonesia to survive in tropical hot, and humid climates. Fluctuating asymmetry (FA) is a random deviation from perfect bilateral symmetry. FA is often used to measure developmental stability in individuals and can be used as a marker for the impact of environmental and genetic stress. This study aims to investigate the pattern of developmental instability in Bali cattle as caused by environmental stress at various altitudes using the FA index. FA indexes in this study were used to compare asymmetrical physical traits of Bali cattle in Sembalun high altitude and Serading low altitude. Sixty-five Bali cattle were used in this study reared at different altitudes, namely Serading, Sumbawa Island (50 m above sea level), and Sembalun, Lombok Island (1,186 m above sea level). The physical traits of Bali cattle measured were horn circumference (horn), a distance of hip to spine bone (pelvic), metatarsal circumference (metatarsal), and metacarpal circumference (metacarpal). The FA1 and FA5 indexes showed significant metacarpal differences between Bali cattle reared at Sembalun and Serading population $(\mathrm{P}<0.05)$. FA11 multiple trait index as a composite of all traits revealed a significant difference as well. $(\mathrm{P}<001)$. It can be concluded that various heat stress by altitude impacts the asymmetry of Bali cattle.

Key Words: Altitude, Bali cattle, Fluctuating asymmetry, Heat stress

\section{INTRODUCTION}

Habitat alteration due to geographical location, latitude, altitude, or human perturbation causes stress, leading directly or indirectly to the animal population's different developmental, growth, and fitness. An animal living in such a habitat should allocate a significant amount of energy to overcome environmental stress while allocating less energy to growth and reproduction (Palmer 1994). Animals can adapt to unfavorable environments through behavioral, physiological, or morphological changes (Niyas et al. 2015; Berihulay et al. 2019). One of the adaptation processes was morphological changes, in which the variations in the level of environmental stress can contribute to the instability development of morphology (Kriegman et al. 2018).

Environmental disturbances cause developmental noise in animals and disrupt the stability of their morphological development, leading to fluctuations 
asymmetry (FA), especially in bilateral organisms (Breed \& Moore 2016). FA is defined as random deviations from perfect symmetry with a normal distribution and a zero mean (Palmer 1994). Its distribution varies amongst populations and is influenced by genetic and environmental variables (de Coster et al. 2013). FA also reflected the organism's inability to buffer its development against random perturbation (Stevenson 2000). Therefore, high-quality individuals (i.e., good genes) can develop more symmetrically than their less well-adapted counterparts, either because they receive more energy or use energy more efficiently (Stevenson 2000; Holló 2017).

FA is practical enough to be widely used and applied across biological systems since it relates to life history and fitness characteristics (van Dongen \& Gangestad 2011; Lajus et al. 2019). FA can be used as a biomarker since it is relatively easy to measure compared to other biomarkers that require more expensive equipment (Coda et al. 2016; Simbula et al. 2021). Some researchers have suggested FA as a marker to estimate how well a population is coping with changes in environmental conditions, especially stressful conditions such as heat shock, radiological, oil spills, and metal contaminants that are expected to persevere for prolonged periods in the environment (Beasley et al. 2013). FA can also be emphasized to estimate fitness since collecting a direct fitness measure from the population in the field is difficult (Baucom \& de Roode 2011; Lajus et al. 2019).

Animals will have different proportions of asymmetry between populations living in disturbed habitats than in natural habitats (Alroy 2017; Teresa Capucchio et al. 2019). Several studies have shown that stressful conditions can cause FA in some populations; the study of Calliphora vicina in various temperature regimes (Limsopatham et al. 2018); bumblebee under various stress conditions (Gerard et al. 2018); several stressors (i.e. natural toxin, parasite, thermic and inbreeding stress) on wing shape and size of bumblebee (Gerard et al. 2018); Caspian whipsnake in diverse stressful habitats due to human disturbance (Bellaagh et al. 2010).

This microclimate created by altitude makes a specific habitat variation from the valley to the top of the mountain for animals living (Wang et al. 2011). The altitude difference directly affects animals' environmental habitat, such as a difference in temperature, humidity, wind speed, and solar radiation. Bali cattle is Indonesia's most adaptive cattle (Martojo 2012) since it can be bred in various environments on Indonesia's humid tropical island. Bali cattle could survive in various environments, such as in Sumatera and Kalimantan oil palm farms, a breeding village in Java and Bali, the steppe and savannah in NTT, and hill and mountain Mt Rinjani. This study aims to use the FA index to investigate the pattern of developmental instability in Bali cattle due to environmental stress due to altitude differences.

\section{MATERIALS AND METHODS}

\section{Sample collection}

Morphological data were collected from the Bali cattle population in October - November 2019, reared at different altitudes to indicate heat stress induction. The first population was chosen at a low altitude of 50 meters above sea level (MSL) at the Center for Livestock Breeding and Forage (BPT-HMT) Serading, Sumbawa Island. The second population was chosen from a high altitude of 1,186 MSL in the village breeding center of Mount Rinjani valley, Sembalun, Lombok Island. A total of 65 cattle was used in this study, with 40 heads in Serading and 25 in Sembalun. Relative humidity (Rh) and ambient temperature (Ta) were measured using a Thermo-Hygrometer which was then calculated into the temperature-humidity index (THI). The condition information of the research location is presented in Table 1 .

\section{Recording of physical parameters}

Physical parameters measured in the study were circumference of horn (horn), hip to spine bone distance (pelvic), metatarsal circumference (metatarsal), and metacarpal circumference (metacarpal). Scales were measured both on the right $(\mathrm{R})$ and left $(\mathrm{L})$ sides. The fluctuations asymmetry of Bali cattle was calculated by comparing their physical parameters using the FA index. The FA index used was FA1, FA5, and FA11. FA for every single trait was compared using FA1 (mean absolute asymmetry: mean $|\mathrm{R}-\mathrm{L}|$ ) and FA5 $(0.798 \sqrt{(\mathrm{R}-\mathrm{L}) 2 / \mathrm{N}}) ; \mathrm{N}=$ number of subjects in the sample). Meanwhile, FA for multiple traits was compared using FA11 [(Ai)/N, (Ai) $=\Sigma|\mathrm{R}-\mathrm{L}|$ for all traits] (Palmer \& Strobeck 2003). The FA1 is simple and common to use, and it can be compared to the other FA. FA5 is effective in detecting small FA differences between populations and is effective in small sample sizes. The FA11 offered a combined comparison of multiple features.

\section{Statistical analysis}

Outlier data for the FA values were excluded by Grubb's test aberrant (de Muth 2019). The Chi-square test calculated independent data on several morphological characters used to develop the FA index. Skew and kurtosis were used to test the normal 
Table 1. The natural conditions of the sampling location

\begin{tabular}{lllllll}
\hline \hline Site & Latitude & Longitude & Altitude & Ta & Rh & THI \\
\hline Serading & $8^{\circ} 34^{\prime} 04^{\prime \prime} \mathrm{S}$ & $117^{\circ} 29^{\prime} 48^{\prime \prime} \mathrm{E}$ & $50 \mathrm{MSL}$ & $30.70 \pm 4.68^{\mathrm{a}}$ & $51.57 \pm 17.42^{\mathrm{a}}$ & $78.79 \pm 3.67^{\mathrm{a}}$ \\
Sembalun & $8^{\circ} 21^{\prime} 48^{\prime \prime} \mathrm{S}$ & $116^{\circ} 31^{\prime} 49 \mathrm{E}$ & $1186 \mathrm{MSL}$ & $23.64 \pm 3.36^{\mathrm{b}}$ & $58.57 \pm 11.22^{\mathrm{b}}$ & $70.51 \pm 4.31^{\mathrm{b}}$ \\
\hline
\end{tabular}

Means in the same column with different superscripts differ significantly $(\mathrm{P}<0.05) . \mathrm{S}=$ south, $\mathrm{E}=$ east, $\mathrm{MSL}=$ meters above sea level, Ta $=$ temperature ambient; $\mathrm{Rh}=$ relative humidity; $\mathrm{THI}=$ temperature-humidity index

Table 2. FA-index representative parameters in two cattle populations

\begin{tabular}{|c|c|c|c|c|c|c|}
\hline \multirow{2}{*}{ Site } & \multirow{2}{*}{ Trait } & \multirow{2}{*}{$\frac{(\mathrm{R}+\mathrm{L})}{2}$} & \multirow{2}{*}{ R-L } & \multicolumn{3}{|c|}{ R-L } \\
\hline & & & & Mean & Skew & Kurtosis \\
\hline \multirow{4}{*}{ Sembalun (24) } & Horn $(\mathrm{cm})$ & 13.55 & 0.31 & 0.06 & 1.95201 & 4.21027 \\
\hline & Pelvis (cm) & 14.69 & 0.13 & -0.04 & 2.42186 & 4.21027 \\
\hline & Metacarpal $(\mathrm{cm})$ & 15.32 & 0.23 & 0.15 & 1.37435 & -0.01901 \\
\hline & Metatarsal $(\mathrm{cm})$ & 19.65 & 0.46 & 0.04 & 2.56753 & 7.07699 \\
\hline \multirow{4}{*}{ Serading (37) } & Horn $(\mathrm{cm})$ & 15.29 & 0.53 & 0.18 & 1.24883 & 1.02443 \\
\hline & Pelvis (cm) & 14.70 & 0.15 & 0.01 & 3.43039 & 11.12044 \\
\hline & Metacarpal $(\mathrm{cm})$ & 14.93 & 0.78 & -0.11 & 1.40628 & 1.58457 \\
\hline & Metatarsal $(\mathrm{cm})$ & 20.20 & 0.81 & -0.08 & 1.96479 & 5.60927 \\
\hline
\end{tabular}

L: the value of the left side; $R$ : the value of the right side

distribution (Palmer \& Strobeck 2003), and a t-test was used to check the expected mean zero (mean absolute FA compared to zero) (Palmer 1994). The FA indexes were analyzed using R Studio (R Studio, BC, Boston, MA, 2020) with Mann Whitney U test (Neuhäuser 2011). Correlations were calculated for each pairwise combination of the four traits across all observations. Correlations between absolute R-L (right-left) cattle size measurements were evaluated using Pearson correlations and FA measurements using Spearman rank correlations (Schober et al. 2018).

\section{RESULT AND DISCUSSION}

There was little available cattle study on phenotypic changes during ontogenetic development, and this study only used morphological data from adult specimens that showed no visible signs of abnormalities. The samples were collected at intermediate age because FA levels were generally lowest at intermediate ages and higher early and late in life (Graham \& Özener 2016). It is because the declining relative growth rate's allometric effects may have been more important at an early stage of life. Later in life, growth may have become less precise due to the accumulation of accidents at a level lower than morphogenesis (Miller \& Zachary 2017).

The use of physical traits such as horn, pelvic, metacarpal, and metatarsal is easily identifiable and quantifiable. These traits refer to previous studies on FA. Several FA studies have used tarsal as part of the calculation due to its relationship to forest landscape connectivity and phenotypic adaptation (Callens et al. 2011; de Coster et al. 2013). The Kruuk et al. (2003) study used antlers (horns) to reference the FA because of their effect on secondary sexual traits and their relationship to growth traits. Pelvic in several studies related to animal carcass size (Van Rooyen et al. 2012; Agamy et al. 2015).

The representative value of physical traits on the right and left sides are presented in Table 2. Bali cattle's mean traits $((\mathrm{R}+\mathrm{L}) / 2)$ in Sembalun high altitude are almost lower than in Serading. The absolute difference between right and left values for each trait reflects the degree of asymmetry relative to the ordinary form; the Serading Bali cattle population has a more significant value deviation than the Sembalun Bali cattle population. Trubyanov \& Glotov (2010) defined skewness and kurtosis as the indication of normal distribution. Skewness is commonly defined as a measure of symmetry or asymmetry datasets with a perfectly symmetrical data set is skewness close to 0 . Kurtosis is mainly about the tails of the distribution and how heavy the tails are. A normal distribution has a kurtosis of 3. The population of Bali cattle in each location is quite asymmetrical since the dataset deviates significantly from the normal distribution as determined by skewness kurtosis analysis.

Only 37 Bali cattle in Serading and 24 in Sembalun were included for the study after eliminating outlier data and outlier asymmetry values by Grubb's test 
Table 3. Correlation of size and FA in all traits with a correlation between trait mean size is above the diagonal, and the absolute FA is below the diagonal.

\begin{tabular}{|c|c|c|c|c|}
\hline & Horn & Pelvic & Metacarpal & Metatarsal \\
\hline Horn & & $0.443 * * *$ & $0.338 * *$ & $0.343 * *$ \\
\hline Pelvic & -0.215 & & $0.568 * * *$ & $0.451 * * *$ \\
\hline Metacarpal & 0.243 & 0.02 & & $0.642 * * *$ \\
\hline Metatarsal & -0.113 & 0.014 & -0.293 & \\
\hline
\end{tabular}

*** indicates $\mathrm{P}<0.001$. There were no significant correlations below the diagonal.

Table 4. Comparisons of FA1, FA5, and FA11 indexes (Mann Whitney-test)

\begin{tabular}{llccc}
\hline \hline FA index & \multicolumn{1}{c}{ Traits } & Sembalun & Serading & Combined \\
\hline \multirow{2}{*}{ FA1 } & Horn & 0.31 & 0.53 & 0.44 \\
& Pelvis & 0.13 & 0.15 & 0.14 \\
& Metacarpal & $0.23^{\mathrm{a}}$ & $0.78^{\mathrm{b}}$ & 0.57 \\
& Metatarsal & 0.46 & 0.81 & 0.67 \\
\hline \multirow{2}{*}{ FA5 } & Horn & 0.25 & 0.42 & 0.35 \\
& Pelvis & 0.10 & 0.12 & 0.11 \\
& Metacarpal & $0.18^{\mathrm{a}}$ & $0.63^{\mathrm{b}}$ & 0.45 \\
\hline FA11 & Metatarsal & 0.37 & 0.64 & 0.54 \\
\hline
\end{tabular}

Superscript shows a significant difference $(\mathrm{P}<0.05)$

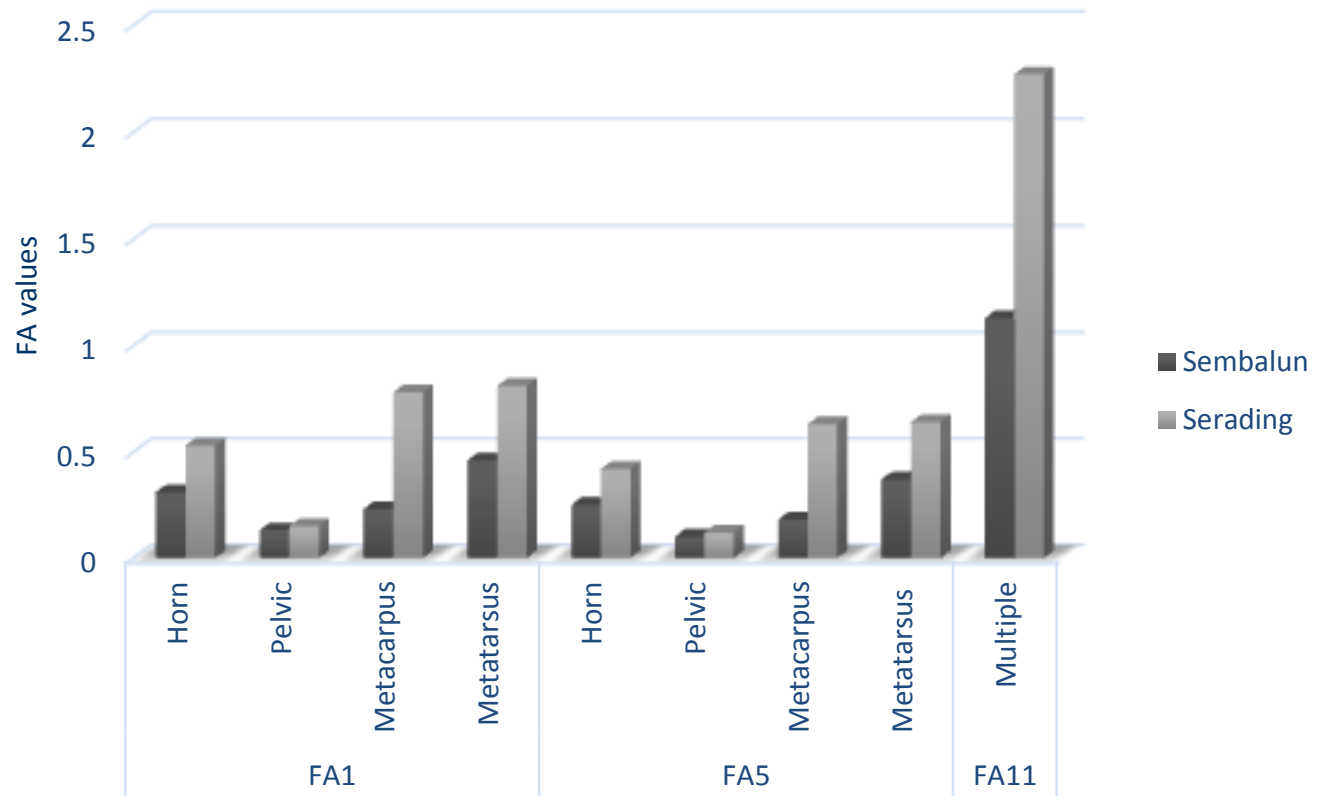

Figure 1. Comparison of FA values of the two cattle populations 
aberrant. According to the Chi-Square test, the horn, pelvic, metacarpal, and metatarsal traits are independent $(\mathrm{P}=0.993)$. The average size of each cattle trait was closely correlated with all other traits, with the highest correlation $(0.642)$ between metacarpal and metatarsal diameter (Table 3). Even after a sequential Bonferroni correction (Sedgwick 2012) for multiple testing, all six pairwise correlations were meaningful at the $5 \%$ level. On the other hand, the absolute FA did not significantly correlate with the four traits (Table 3 ).

The physical traits were calculated into fluctuating asymmetry to assess the index of development instability of Bali cattle. The FA index of physical trait at different altitude are presented in Table 4. The simple indexes of FA1 and FA5 compared each trait to the altitude. However, the multiple indexes of FA11 combined all traits to compare with the altitude. The multiple traits (FA11) were significantly different between the two populations $(\mathrm{P}<0.01)$. While the altitude was compared in each parameter, there was a significant difference in metacarpal trait by using simple indexes of FA1 and FA5. The difference between the other FA scales (horn, pelvic, metatarsal) was insignificant, but the Metatarsal scale shows a nearsignificant differentiation $(\mathrm{P}=0.053)$. The physical traits of the metatarsal and metacarpal diameter could be used to compare the Bali cattle due to different stress habitats. This is in line with the study from Bellaagh et al. (2010) about the Caspian whipsnake population's FA value having significant differences in the FA11 index and simple sublabial index due to differences in stress habitats.

The Mann-Whitney test results from the FA11, $\mathrm{FA} 1_{\text {metacarpal, }}$, and $\mathrm{FA} 5_{\text {metacarpal }}$ indexes showed a significant difference between the Bali cattle population's high-altitude Sembalun and low-altitude Serading. Bali cattle population at low altitude shows a more asymmetrical variation as a phenotypic variation in the metacarpals scale and whole scale as one in FA11. In contrast, the FA1 and FA5 indexes scale in horn, pelvic, and metatarsal showed no significance. The horn and pelvic scale have a high degree of phenotypical stability, not asymmetrical at different stress conditions.

Animals living in uncomfortable environments should allocate a large amount of energy to cope with environmental challenges while less energy is spent on development and reproduction (Palmer 1994). This low energy allocation contributes to low growth (Madhusoodan et al. 2019) or fluctuating asymmetry of the animal (Stevenson 2000). Tuyttens et al. (2005) also discovered a negative relationship between FA and body weight growth in fattening rabbits. Bali cattle acclimated raised in harsh environments had a smaller body size than commercial cattle (Depison et al. 2020) and have lower average daily gain (Marsetyo et al.
2006; Baco et al. 2019). More stressful environments, such as increasing heat stress levels at low altitudes, altered the development stability of Bali cattle, causing them to grow more asymmetrically. This low altitude has higher fluctuation asymmetrical at all traits and all indexes (Figure 1). This continuous situation causes cattle to require more energy to their bodies in order to survive rather than gaining weight.

\section{CONCLUSION}

The metacarpal and metatarsal scales were useful for Bali cattle fluctuating asymmetry studies based on their variance and distribution of asymmetry at the population level. On the other hand, horn and pelvic were less effective in describing the FA in Bali cattle. All four physical traits are easily measured and would be ideal for FA studies. It is concluded that a higher stress level affecting the Bali cattle population might raise the $\mathrm{FA}$.

\section{ACKNOWLEDGEMENT}

This research was funded by the Ministry of Education and Culture for the PMDSU (Pendidikan Magister menuju Doktor untuk Sarjana Unggul) scholarship with contract number: 4124/IT3.L1/PN/2020. The authors thank the head of BPT-HMT Serading and Breeding Village Center Sembalun in West Nusa Tenggara, Indonesia, for the support and facilities provided during the research

\section{REFERENCE}

Agamy R, Abdel-Mone A, Abd-Alla M, Abdel-Mage I, Ashmawi G. 2015. Using linear body measurements to predict body weight and carcass characteristics of three Egyptian fat-tailed sheep breeds. Asian J Anim Vet Adv. 10:335-344. DOI: 10.3923/ajava.2015.335.344.

Alroy J. 2017. Effects of habitat disturbance on tropical forest biodiversity. Proc Natl Acad Sci. 114:6056-6061. DOI: 10.1073/pnas.1611855114.

Baco S, Malaka R, Hatta M, Zulkharnaim. 2019. Pre-weaning performances and mortality rate of calf Bali cattle maintained in the community with smallholder and intensive systems. IOP Conf Ser Earth Environ Sci. 247:012038. DOI: 10.1088/1755-1315/247/1/012038.

Baucom RS, de Roode JC. 2011. Ecological immunology and tolerance in plants and animals. Funct Ecol. 25:18-28. DOI: $10.1111 /$ j. 1365-2435.2010.01742.x.

Beasley DAE, Bonisoli-Alquati A, Mousseau TA. 2013. The use of fluctuating asymmetry as a measure of environmentally induced developmental instability: A meta-analysis. Ecol Indic. 30:218-226. DOI: 10.1016/j.ecolind.2013.02.024. 
Bellaagh M, Lazányi E, Korsós Z. 2010. Calculation of fluctuating asymmetry of the biggest Caspian whipsnake population in Hungary compared to a common snake species. Biologia (Bratisl). 65:140-144. DOI: $10.2478 / \mathrm{s} 11756-009-0219-\mathrm{z}$.

Berihulay H, Abied A, He X, Jiang L, Ma Y. 2019. Adaptation mechanisms of small ruminants to environmental heat stress. Animals. 9:75. DOI: 10.3390/ani9030075.

Breed MD, Moore J. 2016. Animal Behavior. 2nd ed. Colorado (USA): Elsevier Inc.

Callens T, Galbusera P, Matthysen E, Durand EY, Githiru M, Huyghe JR, Lens L. 2011. Genetic signature of population fragmentation varies with mobility in seven bird species of a fragmented Kenyan cloud forest. Mol Ecol. 20:1829-1844. DOI: 10.1111/j.1365294X.2011.05028.x.

Coda J, Gomez D, Martínez JJ, Steinmann A, Priotto J. 2016. The use of fluctuating asymmetry as a measure of farming practice effects in rodents: A species-specific response. Ecol Indic. 70:269-275. DOI: 10.1016/j.ecolind.2016.06.018.

De Coster G, Van Dongen S, Malaki P, Muchane M, Alcántara-Exposito A, Matheve H, Lens L. 2013. Fluctuating asymmetry and environmental stress: Understanding the role of trait history.Saino N, editor. PLoS One. 8:e57966. DOI 10.1371/journal.pone.0057966.

Depison D, Crisdayanti S, Gushairiyanto G, Erina S. 2020. Identifikasi Karakteristik Morfometrik Sapi Bali dan Sapi Brahman Cross di Kecamatan Pamenang Barat Kabupaten Merangin. J Peternak Sriwij. 9:11-20. DOI: 10.33230/JPS.9.2.2020.11945

Van Dongen S, Gangestad SW. 2011. Human fluctuating asymmetry in relation to health and quality: a metaanalysis. Evol Hum Behav. 32:380-398. DOI: 10.1016/j.evolhumbehav.2011.03.002.

Gerard M, Michez D, Debat V, Fullgrabe L, Meeus I, Piot N, Sculfort O, Vastrade M, Smagghe G, Vanderplanck M. 2018. Stressful conditions reveal decrease in size, modification of shape but relatively stable asymmetry in bumblebee wings. Sci Rep. 8:15169. DOI: 10.1038/s41598-018-33429-4.

Graham J, Özener B. 2016. Fluctuating asymmetry of human populations: A review. Symmetry (Basel). 8:154. DOI: 10.3390/sym8120154.

Holló G. 2017. Demystification of animal symmetry: symmetry is a response to mechanical forces. Biol Direct. 12:11. DOI: 10.1186/s13062-017-0182-5.

Kriegman S, Cheney N, Bongard J. 2018. How morphological development can guide evolution. Sci Rep. 8:13934. DOI: $10.1038 / \mathrm{s} 41598-018-31868-7$.

Kruuk LEB, Slate J, Pemberton JM, Clutton-Brock TH. 2003. Fluctuating asymmetry in a secondary sexual trait: no associations with individual fitness, environmental stress or inbreeding, and no heritability. J Evol Biol. 16:101-113. DOI: 10.1046/j.1420-9101.2003.00503.x.
Lajus DL, Golovin P V, Yurtseva AO, Ivanova TS, Dorgham AS, Ivanov M V. 2019. Fluctuating asymmetry as an indicator of stress and fitness in stickleback: A review of the literature and examination of cranial structures. Evol Ecol Res. 20:83-106.

Limsopatham K, Hall MJR, Zehner R, Zajac BK, Verhoff MA, Sontigun N, Sukontason K, Sukontason KL, Amendt J. 2018. A molecular, morphological, and physiological comparison of English and German populations of Calliphora vicina (Diptera: Calliphoridae). Scott MJ, editor. PLoS One. 13:e0207188. ADOI: 10.1371/journal.pone.0207188.

Madhusoodan AP, Sejian V, Rashamol VP, Savitha ST, Bagath M, Krishnan G, Bhatta R. 2019. Resilient capacity of cattle to environmental challenges - An updated review. J Anim Behav Biometeorol. 7:104-118. DOI: 10.31893/2318-1265jabb.v7n3p104-118.

Marsetyo, Pamungkas D, Priyanti A. 2006. Growth perfomance of young bali cattle under varoius feeding management. In: ISTAP. Yogyakarta (Indones): Gadjah Mada University.

Martojo H. 2012. Indigenous Bali cattle is most suitable for sustainable small farming in Indonesia. Reprod Domest Anim. 47:10-14. DOI: 10.1111/j.14390531.2011.01958.x.

Miller MA, Zachary JF. 2017. Mechanisms and Morphology of Cellular Injury, Adaptation, and Death. In: Pathol Basis Vet Dis. Urbana (USA): Elsevier Inc; p. 2-43.e19. DOI: 10.1016/B978-0-323-35775-3.00001-1

de Muth JE. 2019. Tests to Evaluate Potential Outliers. In: AAPS Adv Pharm Sci Ser. New York (USA): Springer; p. 197-210. DOI: 10.1007/978-3-030-33989-0_8.

Neuhäuser M. 2011. Wilcoxon-Mann-Whitney Test. In: Int Encycl Stat Sci. Berlin (DE): Springer Berlin Heidelberg; p. 1656-1658. DOI: 10.1007/978-3-64204898-2_615.

Niyas P, Chaidanya K, Shaji S, Sejian V, Bhatta R, Bagath M, Rao G, Kurlen E, Girish V. 2015. Adaptation of livestock to environmental challenges. J Vet Sci Med Diagn. 04:1000162. DOI: 10.4172/2325-9590.1000162.

Palmer AR. 1994. Fluctuating asymmetry analyses: a primer. In: Dev Instab Its Orig Evol Implic. Dordrecht (NL): Springer; p. 335-364. DOI: 10.1007/978-94-011-08300_26.

Palmer AR, Strobeck C. 2003. Fluctuating asymmetry analyses revisted. In: Polak M, editor. Dev Instab Causes Consequences. Canada (USA): Oxford University Press; p. 279-319.

Van Rooyen I, Fourie P, Schwalbach L. 2012. Relationship between pelvic and linear body measurements in Dorper ewes. S Afr J Anim Sci. 42:498-502. DOI: 10.4314/sajas.v42i5.11.

Schober P, Boer C, Schwarte LA. 2018. Correlation Coefficients: Appropriate use and interpretation. Anesth Analg. 126:1763-1768. DOI: 10.1213/ANE.0000000000002864. 
Sedgwick P. 2012. Multiple significance tests: the Bonferroni correction. BMJ. 344:e509-e509. DOI: 10.1136/bmj.e509.

Simbula G, Vignoli L, Carretero MA, Kaliontzopoulou A. 2021. Fluctuating asymmetry as biomarker of pesticides exposure in the Italian wall lizards (Podarcis siculus). Zoology. $147: 125928$. 10.1016/j.zool.2021.125928.

Stevenson JC. 2000. Asymmetry, developmental stability, and evolution. Am J Hum Biol. 12:720-720. DOI: 10.1002/1520-6300(200009/10)12:5\%3C720::AIDAJHB23\%3E3.0.CO;2-4.

Teresa Capucchio M, Colombino E, Tarantola M, Biagini D, Giovanni Alborali L, Marco Maisano A, Scali F, Raspa F, Valle E, Biasato I, et al. 2019. The Disturbed Habitat and Its Effects on the Animal Population. In: Musarella C, Ortiz A, Canas R, editors. Anim Behav. London (UK): IntechOpen. DOI: 10.5772/intechopen.84872.

Trubyanov AB, Glotov N V. 2010. Fluctuating asymmetry: Trait variation and the left-right correlation. Dokl Biol Sci. 431:103-105. DOI: 10.1134/S0012496610020092.

Tuyttens FAM, Maertens L, Van Poucke E, Van Nuffel A, Debeuckelaere S, Creve J, Lens L. 2005. Measuring fluctuating asymmetry in fattening rabbits: A valid indicator of performance and housing quality?1. J Anim Sci. 83:2645-2652. DOI: 10.2527/2005.83112645x.

Wang K, Sun J, Cheng G, Jiang H. 2011. Effect of altitude and latitude on surface air temperature across the Qinghai-Tibet Plateau. J Mt Sci. 8:808-816. DOI: 10.1007/s11629-011-1090-2. 